\title{
25 Research Square \\ Data calls plate-blocking rule change a win for pro baseball players
}

Gary Green

John D’Angelo

Jon Coyles

lan Penny

John G. Golfinos

Alex Valadka

\section{Video Abstract}

Keywords: rule change, Rule 7.13, home plate, baseball, collisions, traumatic brain injury, professional baseball players, Major League Baseball, Major League Baseball Players Association, safety, concussion, cohort study, catchers, games, player position, MLB, The American Journal of Sports Medicine

Posted Date: November 12th, 2019

DOl: https://doi.org/10.21203/rs.2.17276/v1

License: (c) (i) This work is licensed under a Creative Commons Attribution 4.0 International License.

Read Full License 


\section{Abstract}

In 2014, Major League Baseball, in conjunction with the MLB Players' Association, instituted a controversial rule change designed to prevent home-plate collisions. Rule 7.13 states that a runner attempting to score may not deviate from his direct path to the plate to initiate contact with the catcher. Similarly, the catcher cannot block the runner's path in his bid to score. Some players and managers were initially concerned that the rule would alter the nature of the game. But data show that in the higherstakes matter of player safety, Rule 7.13 is a clear win. Using the MLB Health and Injury Tracking System, a database recording all injuries to players in the major and minor leagues, researchers from MLB and the MLB Players Association looked at how the 2014 rule change has altered the profile of player injuries. Specifically, they compared the incidence of some traumatic brain injuries, or TBIs, in the seasons prior to and after the change. A mild TBI, or concussion, is loosely defined as any complex physiological process affecting the brain as assessed by a physician. While baseball players with mild TBI typically return to play in 7-10 days, there is concern that repetitive impacts have the potential for long-term consequences. Eleven mild TBls caused by home-plate collisions occurred annually before the rule change was made. After, that number dropped to 2 mild TBIs per year. Meanwhile, the total number of days missed on average due to those injuries dropped from 276 to 36 annually. And while none of the mild TBIs recorded after the rule change was season-ending, nearly $20 \%$ of those occurring before the change were. The small number of TBls recorded overall might not be enough to make any definitive claims regarding that type of injury. Notably, however, the researchers witnessed a similar trend when widening their search to any injury due to home-plate collisions: both the annual number of injuries and the time lost to injury dropped significantly. Rule 7.13 doesn't completely eliminate the risk of injury. Even with the allowances runners and catchers now give each other, injuries can and have happened. But the current study and others like it point to the significant benefits rule changes can provide players. Collectively, they're a testament to the ongoing balance stewards of the game must strike between competition and safety. 